ISSN (print): 2706- 6908, ISSN (online): 2706-6894

Vol.15 No.2 June 2020

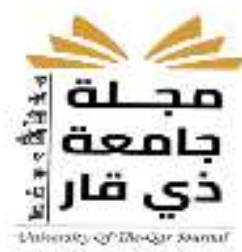

\title{
Preparation and Characterization of New Ligand Azo-Schiff-2- Naphthol and Mixed Complexes With Ortho- Aminophenol and Ortho- Aminobenzoic Acid
}

\author{
Abdulshaheed H. Batay, Mohamed A.Al-hasan \\ Directorate General of Education in Dhi Qar \\ saadalsufi@yahoo.com, saadmohi64@gmail.com \\ https://doi.org/10.32792/utq/uti/vol15/2/2
}

\begin{abstract}
The work covered the synthesis and characterization many complexes of mixed ligands with some ions such as $\mathrm{Co}(\mathrm{II}), \mathrm{Ni}$ (II), $\mathrm{Cu}$ (II) and $\mathrm{Zn}$ (II) metals with new homocyclic azo azomethine ligand 1-((E)-(4-((Z)-1-(p-tolylimino) ethyl) phenyl) diazenyl) naphthalen-2ol(TEPDN) and ligand $\left(\mathrm{HL}_{2}=4-\right.$ Aminoacetophenone $)$ at $(1: 1: 1)$ ratio of $\left(\mathrm{M}: \mathrm{L}_{1}: \mathrm{L}_{2}\right)$ the complexes was characterized by using elemental analysis Uv-Vis and infrared spectra also their prepared complexes war measured by using the same methods in addition of molar conductance measurements, magnetic susceptibility and determined of metal percent in complexes. The physic- chemical studies and spectra data indicate that ( TEPDN ) ligand and another ligand acts as monobasic bidentate ligand after deprotonated of hydroxyl group
\end{abstract}

Keywords: Schiff base, azomethine, Thermal analyses .

\section{Introduction}

Azo-azomethine ligands and their metal complexes have attracted considerable attention due to their impressive and useful chemical and physical properties [1-4]. Apart from their purely chemical interest, azo-azomethine ligands have also received special attention because of their mixed soft hard donor characters ( $\mathrm{O}, \mathrm{N}$ and $\mathrm{S}$ donor sites), versatile coordination behavior [5-7], pharmacological properties [8,9] and optical and thermal properties $[2,10,11]$. Transition metal complexes of azo-azomethine ligands have also attracted special interest because of their optical and absorption properties and also high thermal stability[12]. Metalized azo-azomethine compounds are more stable against light, can provide easier control of the wavelength according to the substituted groups, and have good solubility in many organic solvents. They have been widely used in many practical applications such as printing systems [13,14], photoelectronic materials [15, 16] and also as biological active compounds [2, 17, 18].Transition metal-complexes azomethine 


\section{University of Thi-Qar Journal}

ISSN (print): 2706- 6908, ISSN (online): 2706-6894

\section{Vol.15 No.2 June 2020}

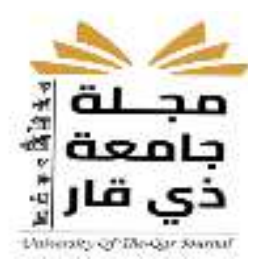

compounds have been studied in great detail in the literature for understanding their optical and electronic properties, structure-redox relationships, and misogynic characteristics[19, 20]. It could be expected that design and synthesis of transition metal complexes derived from azo Schiff base ligands might be a possible way to obtain the applicable nonlinear optical materials [21].

\section{Experimental}

\subsection{Materials}

All of the reagents and solvents involved in synthesis were of analytically grade and used as received without further purification. $P$-Aminoaceto-phenone, $P$-Toluidin, The metal salt $\mathrm{CoCl}_{2} .6 \mathrm{H}{ }_{2} \mathrm{O}, \mathrm{CuCl}_{2} .2 \mathrm{H}_{2} \mathrm{O}, \mathrm{NiCl}_{2} .6 \mathrm{H}_{2} \mathrm{O}, \mathrm{ZnCl}_{2}$ were obtained from Aldrich and Merck.

\subsection{Instrumentation}

FT-IR spectra were recorded as pressed $\mathrm{KBr}$ discs, using Shimadzu FTIR 8400S spectrophotometer in the region of $400-4000 \mathrm{~cm}^{-1}$. Melting points of all newly prepared compounds were determined on Electro thermal 9200 apparatus. Thermal analyses were performed on a Perkin-Elmer Thermogravimetric Analyzer TG/DTA6300 instrument. C. H. $\mathrm{N}$ analy- ses were performed on a Vario EL III elemental analyzer. Metal analyses were made on a Perkin-Elmer 2380 atomic absorption/flame emission spectrophotometer. Electronic spectral measurements were carried out using Perkin-Elmer Lamda spectrophotometer in the range 200-800 $\mathrm{nm}$.Molar conductance of the complexes was measured in ethanol at room temperature using a Digital Conductivity SeriesIno.Lab.720.Magnetic susceptibility of the complexes was performed on a Balance Magnetic Susceptibility Model-M.S.B Auto. mass spectra were recorded byMSD Direct Probe. Using Acq Method low energy.

\subsection{Synthesis}

2.3.1 Synthesis of Azoligand (TEPDN). The diazoniumsalt, N-(1-(4aminophenyl)ethylidene)-4-methylaniline( $2.24 \mathrm{~g}, 10 \mathrm{mmol})$ was added to mixed of $2-$ Aminophenol $(1.44 \mathrm{~g}, 10 \mathrm{mmol})$ in ethanol and $(50 \mathrm{ml})$ of $10 \% \mathrm{NaOH}$, the reaction mixture was concentrated to one-half of the volume and refrigerated for one day. The obtained bright orange colour solid product was filtered and recrystallized from ethanol. The yield obtained was $78 \%$, m.p. $177^{\circ} \mathrm{C}$ the Synthesis of azo Schiff base ligand shown in (Scheme $1)$. 
ISSN (print): 2706- 6908, ISSN (online): 2706-6894

Vol.15 No.2 June 2020
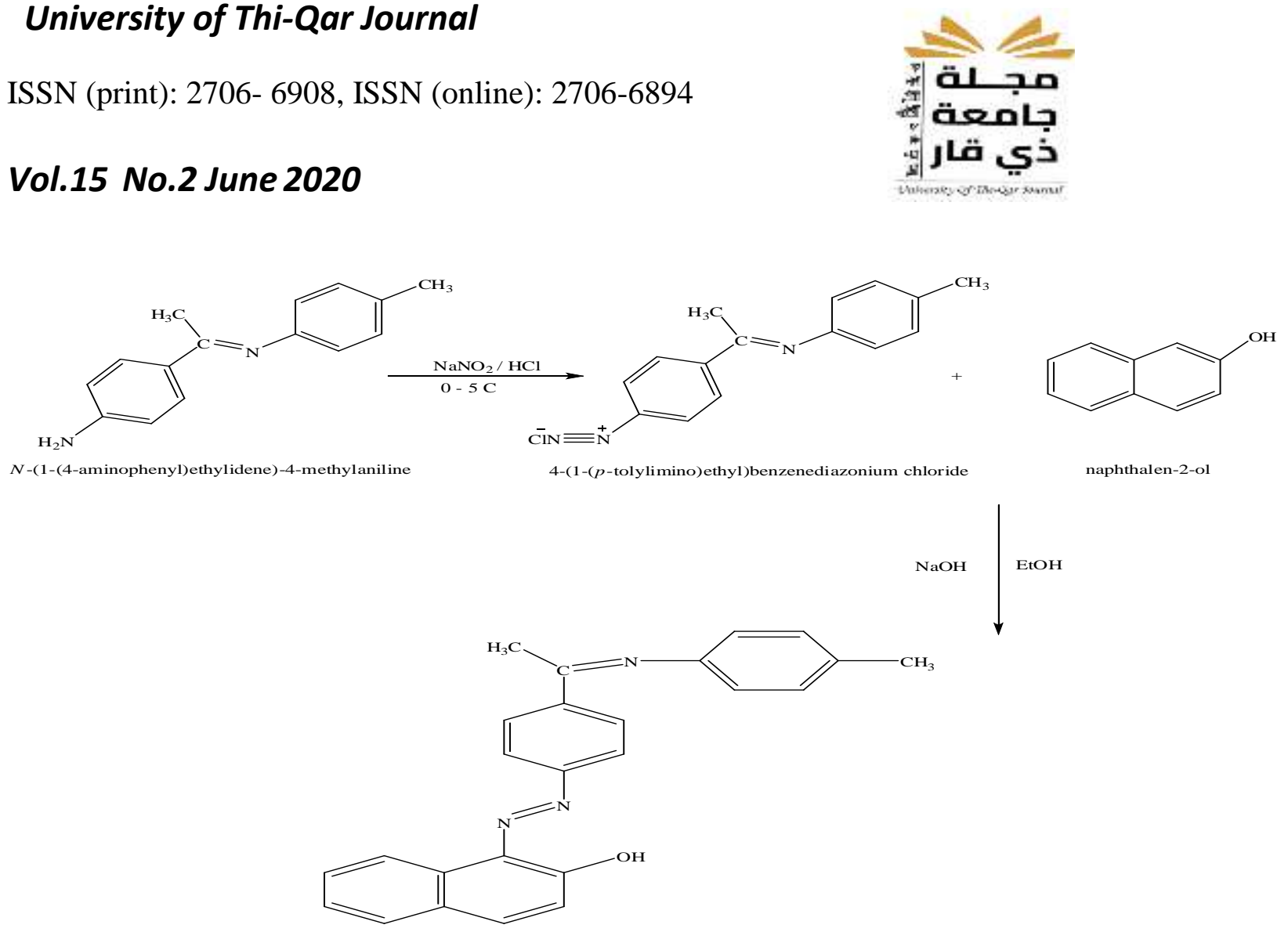

1-(-(4-(1-( $p$-tolylimino)ethyl)phenyl)diazenyl)naphthalen-2-ol ( TEPDN )

SCHEME 1: Synthesis of azo Schiff base ligand.

2.3.2. Synthesis of Metal(II) Complexes. To a solution of mixed ligands $(0.1895 \mathrm{~g}$, $0.5 \mathrm{mmol})$ 1-((E)-(4-((Z)-1- (p-tolylimino) ethyl) phenyl) diazenyl) naphthalen-2-ol (TEPDN) and 4-Aminoacetophenone $(0.0545,0.5 \mathrm{mmol}) \mathrm{in} 50 \mathrm{~mL}$ ethanol wasadded to $0.5 \mathrm{mmol}$ of metal salts $\left(\mathrm{CoCl}_{2} \cdot 6 \mathrm{H} 2 \mathrm{O}, \mathrm{NiCl}_{2} \cdot 6 \mathrm{H} 2 \mathrm{O}, \mathrm{CuCl}_{2} \cdot 2 \mathrm{H}_{2} \mathrm{O}\right.$, and $\left.\mathrm{ZnCl}_{2}\right)$ solution was stirred for $2 \mathrm{~h}$ at $80 \mathrm{C}$. The solution was allowed to settle for $10 \mathrm{~min}$ at ambient temperature . The resulted product was collected by filtration and washed successively with warm $\mathrm{EtOH}$. The obtained solid was dried in air and stored at $50 \mathrm{C}$ overnight. The yield obtained was70-80\%.

\section{Results and Discussion}

The analytical data and physical properties of (TEPDN) and metal(II) complexes are presented in Table 1The complexes are partially soluble in ethanol but soluble in polar coordinating solvents such as DMF The molar conductivities of all the complexes are in the $(10.60-12.55)\left(\Omega-1 \mathrm{~cm} 2 \mathrm{~mol}^{-1}\right)$ range indicating a non electrolyte nature[22].The obtained data showed that the stoichiometry of the chelates is $(1: 1: 1)\left(\mathrm{M}: \mathrm{L}_{1}: \mathrm{L}_{2}\right)$ and the analytical data of the complexes are in good agreement with the general formula $\left[\mathrm{ML}_{1} \mathrm{~L}_{2}\right] \cdot \mathrm{nH}_{2} \mathrm{O}$ for $\mathrm{Cu}$ (II), $\mathrm{Ni}(\mathrm{II}), \mathrm{Co}(\mathrm{II})$, and $\mathrm{Zn}$ (II) complexes where $\mathrm{n}=1,2,4$. 
ISSN (print): 2706- 6908, ISSN (online): 2706-6894

Vol.15 No.2 June 2020

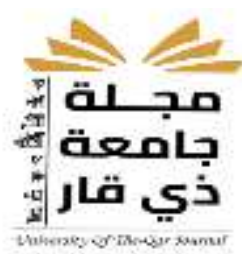

TABLE 1: Physical characterization, analytical and molar conductance data of the ligands and its metal(II) complexes.

3.1. Mass Spectral Studies. The mass spectra of the ligand TEPDN $\left(\mathrm{L}_{1}\right)$ and its complexes were recorded at room temperature, and they are used to compare their stoichiometry composition. The azo Schiff base shows a molecular ion peak at $379 \mathrm{~m} / \mathrm{z}$. Molecular ion peak for the $\mathrm{Zn}(\mathrm{II})$ complex observed at $597 \mathrm{~m} / \mathrm{z}$ confirms the stoichiometry of metal chelates as $\left[\mathrm{ML}_{1} \mathrm{~L}_{2}\right] \cdot \mathrm{H}_{2} \mathrm{O}$ type. The mass spectra of the ligand and its zinc (II) complex are

\begin{tabular}{|c|c|c|c|c|c|c|c|c|}
\hline \multirow{2}{*}{ Cheimiecal formul } & \multirow{2}{*}{$\begin{array}{c}\text { Symbol } \\
\text { e }\end{array}$} & \multirow{2}{*}{ M.wt } & \multirow{2}{*}{$\underset{{ }_{0}^{\text {m.p }} \mathrm{C}}{\mathbf{m}}$} & \multicolumn{4}{|c|}{ Found (calc.) \% } & \multirow{2}{*}{$\begin{array}{c}\Lambda \mathrm{M}(\Omega-1 \\
\mathrm{cm} 2 \\
\mathrm{~mol}-1)\end{array}$} \\
\hline & & & & $\mathbf{C}$ & $\mathbf{H}$ & $\mathbf{N}$ & $\mathbf{M}$ & \\
\hline$\left(\mathrm{C}_{25} \mathrm{H}_{21} \mathrm{~N}_{3} \mathrm{O}\right)=\mathrm{HL}_{1}$ & $\underset{(}{\text { TEPDN }}$ & 379 & $\begin{array}{l}176- \\
177\end{array}$ & $\begin{array}{c}76.8 \\
3 \\
(79.1 \\
3) \\
\end{array}$ & $\begin{array}{l}5.42 \\
(5.5 \\
8)\end{array}$ & $\begin{array}{c}10.8 \\
9 \\
(11.0 \\
7)\end{array}$ & ---- & , \\
\hline$\left(\mathrm{C}_{7} \mathrm{H}_{7} \mathrm{NO}_{2}\right)=\mathrm{HL}_{2}$ & $\begin{array}{c}2- \\
\text { Amino- } \\
\text { benzoic } \\
\text { acid }\end{array}$ & $\begin{array}{c}137.1 \\
4\end{array}$ & 146 & ------ & ---- & ---- & ------ & -------- \\
\hline $\begin{array}{c}{[\mathrm{Cu}} \\
\left.\left(\mathrm{C}_{32} \mathrm{H}_{26} \mathrm{~N}_{4} \mathrm{O}_{3}\right)\right] \cdot 4 \mathrm{H}_{2} \\
\mathrm{O}\end{array}$ & $\mathbf{M}_{1}$ & $\begin{array}{c}650.1 \\
2\end{array}$ & $\begin{array}{l}198- \\
199\end{array}$ & $\begin{array}{c}58.9 \\
1 \\
(59.1 \\
1)\end{array}$ & $\begin{array}{c}5.13 \\
(5.2 \\
7)\end{array}$ & $\begin{array}{c}8.46 \\
(8.62 \\
)\end{array}$ & $\begin{array}{c}9.58 \\
(9.77 \\
)\end{array}$ & 12.55 \\
\hline $\begin{array}{c}{[\mathrm{Co}} \\
\left.\left(\mathrm{C}_{32} \mathrm{H}_{26} \mathrm{~N}_{4} \mathrm{O}_{3}\right)\right] \cdot 2 \mathrm{H}_{2} \\
\mathrm{O}\end{array}$ & $\mathbf{M}_{2}$ & $\begin{array}{c}609.5 \\
1\end{array}$ & $\begin{array}{l}165- \\
166\end{array}$ & $\begin{array}{c}62.8 \\
7 \\
(63.0 \\
5) \\
\end{array}$ & $\begin{array}{l}4.84 \\
(4.9 \\
6)\end{array}$ & $\begin{array}{c}8.82 \\
(9.19 \\
)\end{array}$ & $\begin{array}{c}9.72 \\
(9.67 \\
)\end{array}$ & 11.31 \\
\hline $\begin{array}{c}{[\mathrm{Ni}} \\
\left.\left(\mathrm{C}_{32} \mathrm{H}_{26} \mathrm{~N}_{4} \mathrm{O}_{3}\right)\right] \cdot \mathrm{H}_{2} \mathrm{O}\end{array}$ & $\mathbf{M}_{3}$ & $\begin{array}{c}591.2 \\
7\end{array}$ & $\begin{array}{l}-185 \\
183\end{array}$ & $\begin{array}{c}64.7 \\
8 \\
(65.0 \\
0)\end{array}$ & $\begin{array}{c}4.65 \\
(4.7 \\
7)\end{array}$ & $\begin{array}{c}9.21 \\
(9.48 \\
)\end{array}$ & $\begin{array}{c}9.61 \\
(9.93 \\
)\end{array}$ & 12.21 \\
\hline $\begin{array}{c}{\left[\mathrm{Zn}\left(\mathrm{C}_{32} \mathrm{H}_{26} \mathbf{N}_{4} \mathrm{O}_{3}\right]\right.} \\
\left.\mathbf{H}_{2} \mathrm{O}\right)\end{array}$ & $\mathbf{M}_{4}$ & $\begin{array}{c}615.9 \\
8\end{array}$ & $\begin{array}{l}-172 \\
170\end{array}$ & $\begin{array}{c}62.1 \\
7 \\
(62.3 \\
9)\end{array}$ & $\begin{array}{c}4.78 \\
(4.9 \\
1)\end{array}$ & $\begin{array}{c}8.93 \\
(9.10 \\
)\end{array}$ & $\begin{array}{c}10.3 \\
9 \\
(10.6 \\
2)\end{array}$ & 10.60 \\
\hline
\end{tabular}


University of Thi-Qar Journal

ISSN (print): 2706- 6908, ISSN (online): 2706-6894

Vol.15 No.2 June 2020

shown in Figure1.

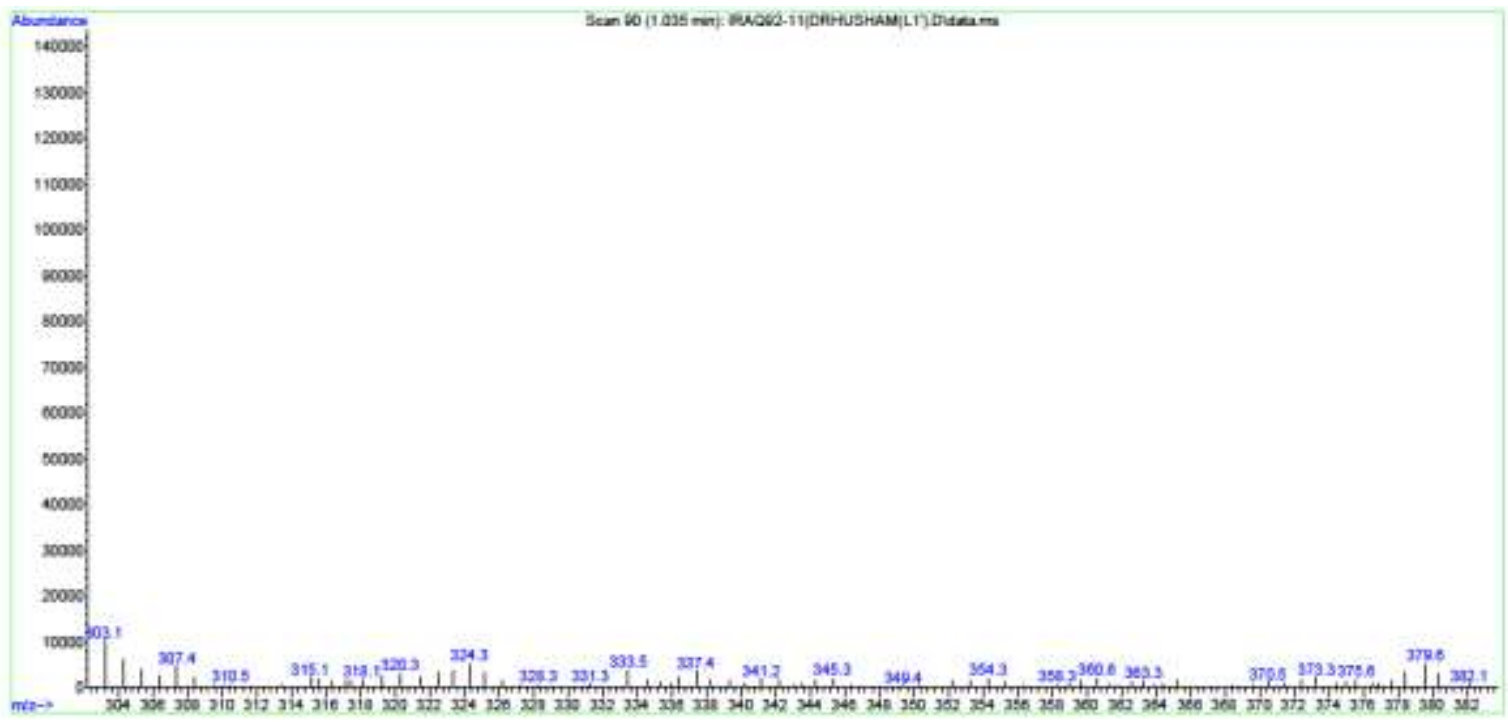

( a )

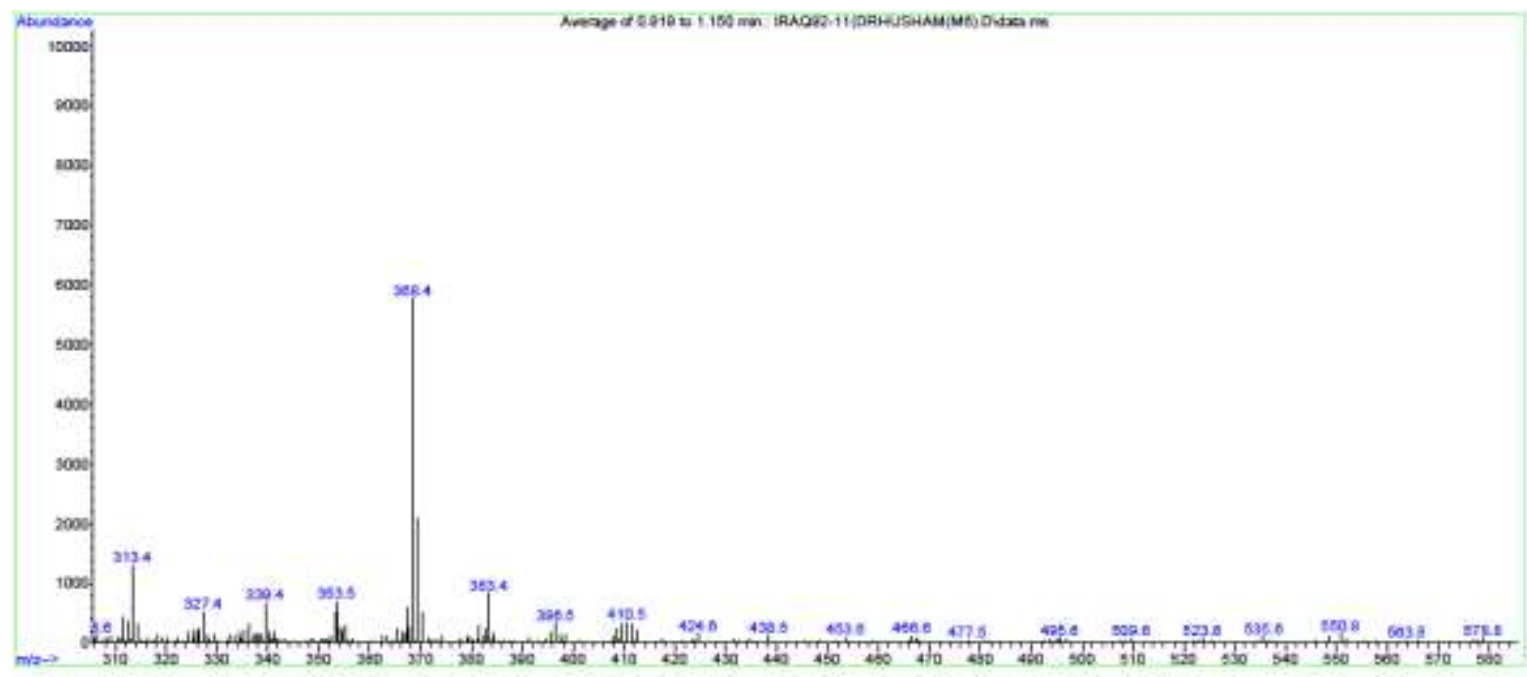

( b )

FIGURE1: Mass spectra of (a) [TEPDN], (b) [ $\left.\mathrm{Zn}\left(\mathrm{L}_{1}\right)\left(\mathrm{L}_{2}\right) \cdot \mathrm{H}_{2} \mathrm{O}\right]$. 


\section{University of Thi-Qar Journal}

ISSN (print): 2706- 6908, ISSN (online): 2706-6894

\section{Vol.15 No.2 June 2020}

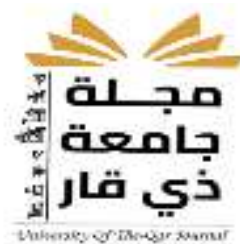

3.2. IR Spectral Studies. The characteristic IR spectral data of the ligands and its complexes are given in (Table 2). The detected band at $1598 \mathrm{~cm}^{-1}$ is assigned to the stretching vibration of the azo group of the ligand TEPDN. This band is shifted in the complexes toward lower frequencies $\left(1530-1566 \mathrm{~cm}^{-1}\right)$ because of the participation of the nitrogen atom to coordinate with metal ion. This fact can be explained by the withdrawing of electrons from nitrogen atom to the metal ion due to coordination process [23].The bands around $3440 \mathrm{~cm}^{-1}$ and $1261 \mathrm{~cm}^{-1}$ are assigned to $\left(\mathrm{O}^{-} \mathrm{H}\right)$ vibration and the carboxylic $\mathrm{C}^{-} \mathrm{O}$ vibration, respectively. However, in the spectra of the metal complexes the $\mathrm{C}^{-} \mathrm{O}$ bands underwent a shift towards higher frequencies $\sim 40 \mathrm{~cm}^{-1}$, and this shift confirms the participation of oxygen in the $\mathrm{C}^{-}$ $\mathrm{O}-\mathrm{M}$ bond . $\mathrm{Cu}(\mathrm{II}), \mathrm{Co}(\mathrm{II}), \mathrm{Ni}(\mathrm{II})$, and $\mathrm{Zn}(\mathrm{II})$ complexes show a broadband at $\sim 3400 \mathrm{~cm}^{-1}$ due to the vibrations of hydrated water molecules [24].The band at $1676 \mathrm{~cm}^{-1}$ is assigned to the stretching vibration of the azomethine group and the spectra of the complexes did not show any frequency shift of the $\mathrm{C}=\mathrm{N}$ - band, which may be explained by nonparticipation of azomethine group in complex formation [25].The band of medium intensity observed for the complexes in the region580-594 $\mathrm{cm}^{-1}$ is attributed tov $(\mathrm{M}-\mathrm{N})$ and in the region480-500 $\mathrm{cm}^{-1}$ to $v(\mathrm{M}-\mathrm{O})$ [26].

TABLE2: IR spectral data of ligands and its mixed metal(II) complexes $\left(\mathrm{cm}^{-1}\right)$.

\begin{tabular}{|c|c|c|c|c|c|c|c|c|c|}
\hline Comp. & $\begin{array}{c}v(\mathrm{O}-\mathrm{H}) \\
\mathrm{H}_{2} \mathrm{O} \\
\text { hyd- }\end{array}$ & $\begin{array}{l}v(\mathrm{C}- \\
\mathrm{H})_{\mathrm{ar}} .\end{array}$ & $\begin{array}{l}v(\mathrm{C}- \\
\mathrm{H})_{\mathrm{al}} .\end{array}$ & $v(\mathrm{~N}-\mathrm{H})$ & $\begin{array}{c}v \\
(C=N)\end{array}$ & $\begin{array}{c}v \\
(\mathrm{~N}=\mathrm{N})\end{array}$ & $\begin{array}{c}v(\mathrm{C}-\mathrm{O}) \\
\text { carbox } \\
\text { ylic }\end{array}$ & $\begin{array}{l}v(\mathrm{M}- \\
\mathrm{N})\end{array}$ & $\begin{array}{c}v(\mathbf{M}- \\
\text { O) }\end{array}$ \\
\hline $\mathrm{HL}_{1}$ & 3442 w & 3047 w & 2958 w & --------- & $\begin{array}{c}1676 \\
\mathrm{~m}\end{array}$ & $\begin{array}{c}1598 \\
w\end{array}$ & $1261 \mathrm{~s}$ & --- & --- \\
\hline $\mathrm{HL}_{2}$ & $3323 \mathrm{w}$ & $3050 \mathrm{w}$ & ------ & 3238 & ----- & ------- & $1260 \mathrm{~s}$ & ------ & ------ \\
\hline $\begin{array}{l}{\left[\mathrm{CuL}_{1} \mathrm{~L}_{2}\right] .4} \\
\mathrm{H}_{2} \mathrm{O}\end{array}$ & $3423 w$ & $3055 \mathrm{w}$ & 2935 w & 3176 & $\begin{array}{c}1678 \\
\mathrm{~m}\end{array}$ & $\begin{array}{c}1530 \\
w\end{array}$ & $1311 \mathrm{w}$ & $501 \mathrm{w}$ & $582 w$ \\
\hline $\begin{array}{l}{\left[\mathrm{CoL}_{1} \mathrm{~L}_{2}\right] .2} \\
\mathrm{H}_{2} \mathrm{O}\end{array}$ & 3481 w & $3057 \mathrm{w}$ & $3000 \mathrm{w}$ & 3421 & $\begin{array}{l}1674 \\
\mathrm{~m}\end{array}$ & $\begin{array}{l}1539 \\
w\end{array}$ & 1315 w & $489 w$ & $584 w$ \\
\hline $\begin{array}{l}{\left[\mathrm{NiL}_{1} \mathbf{L}_{2}\right] \cdot \mathbf{H}_{2}} \\
\mathbf{O}\end{array}$ & $3483 w$ & $3059 w$ & 2875 w & 3408 & $\begin{array}{c}1680 \\
\mathrm{~m}\end{array}$ & $\begin{array}{c}1544 \\
\text { w }\end{array}$ & 1305 w & $499 w$ & $588 w$ \\
\hline
\end{tabular}


University of Thi-Qar Journal

ISSN (print): 2706- 6908, ISSN (online): 2706-6894

Vol.15 No.2 June 2020

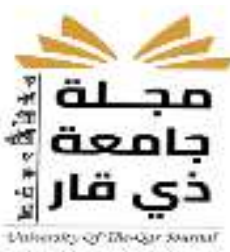

\begin{tabular}{|l|c|c|c|c|c|c|c|c|c|}
\hline $\begin{array}{l}{\left[\mathrm{ZnL}_{1} \mathrm{~L}_{2}\right] .} \\
\mathrm{H}_{2} \mathrm{O}\end{array}$ & $3522 \mathrm{w}$ & $3055 \mathrm{w}$ & $2920 \mathrm{w}$ & 3388 & $\begin{array}{c}1670 \\
\mathrm{~m}\end{array}$ & $\begin{array}{c}1566 \\
\mathrm{w}\end{array}$ & $1315 \mathrm{w}$ & $487 \mathrm{w}$ & $590 \mathrm{w}$ \\
\hline
\end{tabular}

\subsection{Thermal Properties}

Thermal stability and decomposition behavior of (TEPDN) and $\mathrm{Cu}$ (II) complex have been studied TGA in the flowing atmosphere of air in the temperature range $50-900{ }^{\circ} \mathrm{C}$, Table 3.The TGA curves of $\left(\mathrm{HL}_{1}\right)$ and $\left(\mathrm{M}_{1}\right)$ are presented in Fig. 3From the TGA data it can be seen that the $\left(\mathrm{HL}_{1}\right)$ show no any mass loss up to $290{ }^{\circ} \mathrm{C}$, indicating the absence of water and any other adsorptive solvent molecules in the coordination sphere [26,27].Whereas, the TG curves of $\left(\mathrm{M}_{1}\right)$ show a mass loss of $10.7 \%$ within the temperature range $50-145^{\circ} \mathrm{C}$ corresponds to the loss four molecules of hydration water (calc. 11.07).The complex $\left(\mathrm{M}_{1}\right)$ was thermally decomposed in two successive decomposition steps. The second decomposition step of estimated mass loss $25.48 \%$ above $300{ }^{\circ} \mathrm{C}$ may be attributed to the loss of the $\left(\mathrm{C}_{10} \mathrm{H}_{6} \mathrm{~N}_{2} \mathrm{O}\right)$ (calc. $\left.26.10 \%\right)$.

TABLE 3: Thermal analyses data for $\left(\mathrm{TEPDN}=\mathrm{HL}_{1}\right)$ and $\left(\mathrm{M}_{1}\right)$

\begin{tabular}{|l|l|l|l|l|}
\hline $\begin{array}{l}\text { Compound } \\
(\mathrm{M} . \mathrm{Wt})\end{array}$ & $\begin{array}{l}\text { Dissociatio } \\
\mathrm{n} \\
\text { stages }\end{array}$ & $\begin{array}{l}\text { Temp.rang } \\
\mathrm{e} \\
\text { In TG }\left(\mathrm{C}^{\circ}\right)\end{array}$ & $\begin{array}{l}\text { Weight loss } \\
\text { Found } \\
\text { (calc. })\end{array}$ & $\begin{array}{l}\text { Decompositio } \\
\mathrm{n} \\
\text { assignment }\end{array}$ \\
\hline $\begin{array}{l}\left(\mathrm{C}_{25} \mathrm{H}_{21} \mathrm{~N}_{3} \mathrm{O}\right)=\mathrm{HL}_{1} \\
(379)\end{array}$ & $\begin{array}{l}\text { Stage I } \\
\text { Stage II }\end{array}$ & $\begin{array}{l}50-280 \\
290-577\end{array}$ & $\begin{array}{l}4.21(4.23) \\
61.48(62.26 \\
)\end{array}$ & $\begin{array}{l}\text { Loss of }\left(\mathrm{CH}_{4}\right) \\
\text { Loss } \\
\text { of }\left(\mathrm{C}_{15} \mathrm{H}_{14} \mathrm{~N}_{3}\right)\end{array}$ \\
\hline $\begin{array}{l}{\left[\mathrm{Cu}\left(\mathrm{C}_{31} \mathrm{H}_{26} \mathrm{~N}_{4} \mathrm{O}_{2}\right)\right] .4 \mathrm{H}_{2}} \\
\mathrm{O}\end{array}$ & $\begin{array}{l}\text { Stage I } \\
\text { Stage II }\end{array}$ & $\begin{array}{l}50-145 \\
155-299\end{array}$ & $\begin{array}{l}10.7(11.07) \\
25.48 \\
(26.10)\end{array}$ & $\begin{array}{l}\text { Loss of } \\
\left(4 \mathrm{H}_{2} \mathrm{O}\right) \\
\text { Loss of } \\
\left(\mathrm{C}_{10} \mathrm{H}_{6} \mathrm{~N}_{2} \mathrm{O}\right)\end{array}$ \\
\hline
\end{tabular}


ISSN (print): 2706- 6908, ISSN (online): 2706-6894

\section{Vol.15 No.2 June 2020}
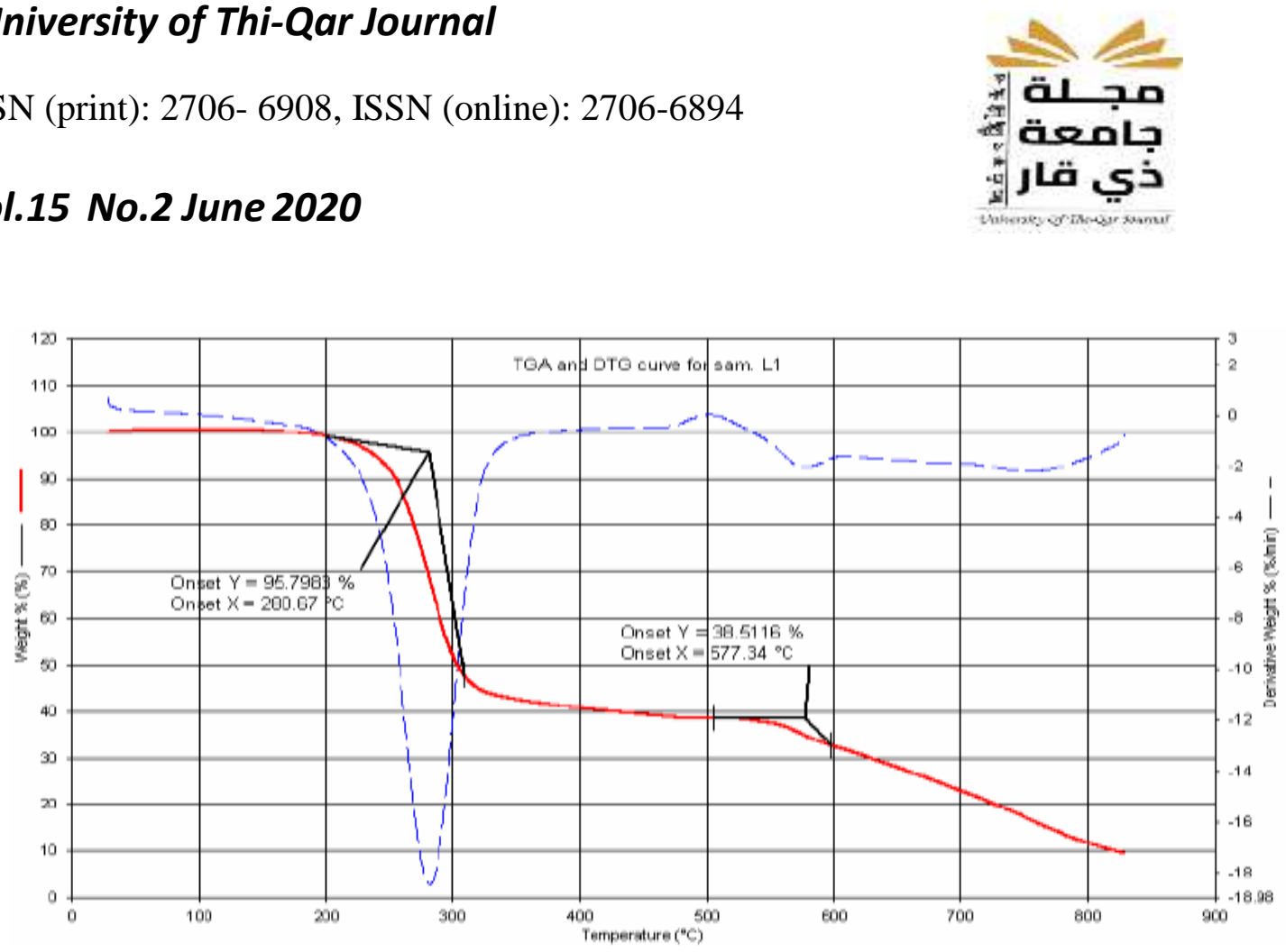

FIGURE 2: TGA analyses curves of $\left(\mathrm{HL}_{1}\right)$ ligand .

3.4. Electronic Spectral and Magnetic Susceptibility Studies .The electronic spectra of TEPDN $\left(\mathrm{HL}_{1}\right)$ and its complexes were recorded in ethanol. The absorption spectrum of the ligand shows strong peaks at 317 and $286 \mathrm{~nm}$ which may be assigned to $\left(\mathrm{n} \rightarrow \pi^{*}\right)$ (transitions of the $-\mathrm{CH}=\mathrm{N}$-and $-\mathrm{N}=\mathrm{N}^{-}$groups) and $\left(\pi \rightarrow \pi^{*}\right)$ (transition of $-\mathrm{N}=\mathrm{N}^{-}$azo group) transitions respectively[28,29],the spectral data of the ligand and its complexes given in Table 4.The spectra of the mixed ligands of $\mathrm{Cu}$ (II), $\mathrm{Co}$ (II) , $\mathrm{Zn}$ (II) complexes show peaks in the region at $489-500 \mathrm{~nm}$ which can be assigned to charge transfer $\mathrm{L} \rightarrow \mathrm{M}$ bands[30,31].The nickel(II) complex exhibits $\mathrm{d}$-d bands at $487 \mathrm{~nm}$, due to ${ }^{1} \mathrm{~A}_{1 \mathrm{~g}} \rightarrow{ }^{1} \mathrm{~B}_{1 \mathrm{~g}}$ transitions which arises from an square- planer structure. The magnetic moment value of the cobalt(II) complex 3.63 B.M. confirms the tetrahedral geometry [32].The magnetic moment value1.37 B.M. falls within the range normally observed for square planar $\mathrm{Cu}(\mathrm{II})$ complexes [33]. The $\mathrm{Zn}$ (II) , Ni(II) complexes has been found to be diamagnetic in nature confirms the tetrahedral geometry for $\mathrm{Zn}$ (II) mixed ligands complex[34] and square planar for $\mathrm{Ni}(\mathrm{II})$ complex[34]

TABELE 4: Electronic spectral data of ligands and its metal(II) mixed ligand complexes.

\begin{tabular}{|l|l|l|l|l|}
\hline Compound & Assigument & Absorption band(n.m) & $\mu_{\text {eff }}$ (B.M) & Proposed Structure \\
\hline
\end{tabular}




\section{University of Thi-Qar Journal}

ISSN (print): 2706- 6908, ISSN (online): 2706-6894

Vol.15 No.2 June 2020

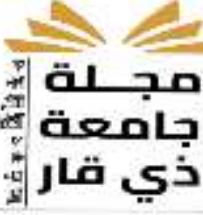

\begin{tabular}{|c|c|c|c|c|}
\hline $\mathrm{HL}_{1}$ & $\begin{array}{c}\mathrm{n} \rightarrow \pi^{*} \& \\
\pi \rightarrow \pi^{*}\end{array}$ & $\begin{array}{c}317,488 \\
227,286\end{array}$ & --- & --- \\
\hline $\mathrm{HL}_{2}$ & $\begin{array}{c}\mathrm{n} \rightarrow \pi^{*} \\
\pi \rightarrow \pi^{*}\end{array}$ & $\begin{array}{l}336 \\
260\end{array}$ & ---- & ---- \\
\hline$\left[\mathrm{Cu}\left(\mathrm{L}_{1}\right)\left(\mathrm{L}_{2}\right)\right] \cdot 4 \mathrm{H}_{2} \mathrm{O}$ & C. T. & 508 & 1.37 & Sq.P \\
\hline$\left[\mathrm{Co}\left(\mathrm{L}_{1}\right)\left(\mathrm{L}_{2}\right)\right] \cdot 2 \mathrm{H}_{2} \mathrm{O}$ & C. T. & 488 & 3.63 & $\mathrm{Td}$ \\
\hline$\left[\mathrm{Ni}\left(\mathrm{L}_{1}\right)\left(\mathrm{L}_{2}\right)\right] \cdot \mathrm{H}_{2} \mathrm{O}$ & ${ }^{1} \mathrm{~A}_{1 \mathrm{~g}} \rightarrow{ }^{1} \mathrm{~B}_{1 \mathrm{~g}}$ & 487 & Dia & Sq.P \\
\hline$\left[\mathrm{Zn}\left(\mathrm{L}_{1}\right)\left(\mathrm{L}_{32}\right)\right] \cdot \mathrm{H}_{2} \mathrm{O}$ & C. T. & 489 & Dia & $\mathrm{Td}$ \\
\hline
\end{tabular}

\section{References}

1. E. I'spir, (2009) Dye Pigment 82, 13

2. Z. Ye, L. DeBoni, U.M. Neves, C.R. Mendonc sa, X.R. Bu, (2009)Tetrahedron Lett. 50, 1371

3. R. Chinchilla, C. Na'jera, M. Yus, (2004) Chem. Rev. 104, 2667

4. S. Brooker, T.C. Davidson, S.J. Hay, R.J. Kelly, D.K. Kennepohl, P.G. Plieger, D. Moubaraki, K.S. Murrey, E. Bill, E. Bothe, (2001) Coord. Chem. Rev. 216-217, 3

5. H. Dinc, aple, F. Toker, I'. Durucasu, N. Avcibas,i, S. Icli, (2007) Dye Pigment 75, 11

6. S. Roy, T.N. Mandal, A.K. Barik, S. Pal, S. Gupta, A. Hazra, A.J. Butcher, A.D. Hunter, M. Zeller, S.K. Kar, (2007) Polyhedron 26, 2603

7. A.D. Naik, S.M. Annigeri, U.B. Gangadharmath, V.K. Revankar, V.B. Mahale, (2002) Spectrochim. Acta Part A 58, 1713

8. M. Odabas, og lu, C, . Albayrak, R. O־ zkanca, F.Z. Aykan, P. Lonecke, J. Mol. Struct. (2007) 840,71

9. D. Zhang, M. Zhang, Z. Liu, M. Yu, F. Li, T. Yi, C. Huang, (2006) Tetrahedron Lett. 47, 7093

10. U.M. Neves, L. DeBoni, Z. Ye, X.R. Bu, C.R. Mendonc sa, (2007)Chem. Phys. Lett. 441, 221

11. Y. Geng, D.D. Gu, F.X. Gan, Matt. (2004) Sci. Eng. B 110, 115

12. P. Pattanyak, J.L. Pratihar, D. Patra, V.G. Puranik, S. Chattopadhyay, (2008)Polyhedron 27, 2209 


\section{University of Thi-Qar Journal}

ISSN (print): 2706- 6908, ISSN (online): 2706-6894

\section{Vol.15 No.2 June 2020}

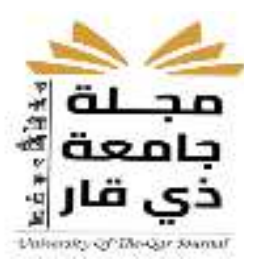

13. W. Herbst, K. Hunger, (1997) Industrial organic pigments: production, properties, applications, 2nd edn. (VCH, Weinheim,)

14. T.P. Smith, D.W. Malcomber, M.A. Elmastry, (1992) US Patent 5,166,326,

15. Y.Z. Gu, F.X. Gan, S.Q. Wang, H.J. Xu, (2001) Optics Comm. 197, 501

16. W. Chen, Y.Q. Wu, D.D. Gu, F.X. Gan, (2007) Matter. Lett. 61, 4181

17. S. Alghool, H.F. Abd El-Halim, A. Dahshan, (2010)J. Mol. Struct. 983, 32

18. M. Kurtog lu, E. I’spir, N. Kurtog`lu, S. Serin, (2008) Dye Pigment 77, 75

19. P. A. Vigato and S. Tamburini, (2004). "The challenge of cyclic and acyclic schiff bases and related derivatives," Coordination Chemistry Reviews, vol. 248, no. 17-20, pp. 1717-2128,

20. I. Sheikhshoaie and W. M. F. Fabian, "Quantum chemical study on the electronic structure and second-order nonlinear optical properties of salen-type Schiff bases," (2006) , Dyes and Pigments, vol. 70, no. 2, pp. 91-98 .

21. F. Tisato, F. Refosco, and G. Bandoli, (1994), "Structural survey of technetium complexes," Coordination Chemistry Reviews, vol. 135-136, pp. 325-397 .

22. S.A. Kettle; (1975)"Coordination Compounds" Thomas Nelson and Sons, London, 3, 186, 212.

23. K. Nejati and Z. Rezvani, (2003), "Syntheses, characterization and mesomorphic properties of new bis(alkoxyphenylazo)- substituted N,N' salicylidenediiminato $\mathrm{Ni}(\mathrm{II})$, $\mathrm{Cu}(\mathrm{II})$ and $\mathrm{VO}(\mathrm{IV})$ complexes," The New Journal of Chemistry, vol. 27, no. 11, pp. $1665-1669$.

24. G. G. Mohamed, (2001) , "Structural chemistry of some new azo complexes," SpectrochimicaActa A, vol. 57, no. 3, pp. 411-417.

25. E. Erdem, E. Y. Sari, R. Kilincarslan, and N. Kabay, ( 2009), "Synthesis and characterization of azo-linked Schiff bases and theirnickel(II), copper(II), and zinc(II) complexes," Transition Metal Chemistry, vol. 34, no. 2, pp. 167-174

26. G. G. Mohamed and S. M. Khalil, (2009) "Metal complexes of omeprazole. Preparation, spectroscopic and thermal characterization and biological activity," Journal of Coordination Chemistry, vol. 62, no. 4, pp. 645-654,.

27.K.Y. El-Baradie ; (2005) Mona. for Chem. , 136 , 1139-1155 ,. 


\section{University of Thi-Qar Journal}

ISSN (print): 2706- 6908, ISSN (online): 2706-6894

\section{Vol.15 No.2 June 2020}

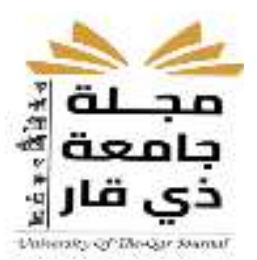

28.H. Khanmohammadi and m. Darvishpour ; (2011) J . Inor. Org. Pdy. ., 21 , 541-546 .

29.M. G. Tay, Z. Ngaini, M. A. M. Arif, N. M. Sarih, W. M. Khairul, S. P. Lau, and E. Enggie; Borneo, (2013) J. of Resource Science and Technology., 3(1), 26.

30.D.D. Nasrin1, M. A. Alam, M. N. Hossain, and M. Nazimuddin; (2013).Chem. J., 3(1), 13.

31.S. Sarkar, S. Biwas, M. Sliao, T. Kar, Y. Aydogdu, F. Dagdelen, G. Mostafa , A. P. Chahopadlhyay, G. P. A. Yap, R.-H. Xie, A. T. Khan and K. Dey; (2008). Polyhedron., 27, 3359.

32.M. M. Jagadale, M. R. Asabe, and V. P. Ubale; International(2013). J. of Engineering Science Invention., 2319, 48.

33. K. S. Kumar, V. K. Chityala, N. J. P. Subhashini, Y. Prashanthi, and Shivaraj; (2013).ISRN Inorganic Chem.

34.W. G. Hanna and M. M. Moawad, (2001). "Synthesis, characterization and antimicrobial activity of cobalt(II), nickel(II)and copper(II) complexes with new asymmetrical Schiff base ligands derived from 7-formyanil-substituted diamine-sulphoxine and acetylacetone," Transition Metal Chemistry, vol. 26, no. 6, pp. 644-651. 